\title{
Stratigraphy and paleogeography of the Eocene in the Mosqueiro Low, Sergipe-Alagoas Basin
}

\author{
Cristiano Camelo Rancan ${ }^{*}$ (D), Rosemarie Rohn² (D, Wagner Souza-Lima ${ }^{3}$ (D, Claudio Borba' (D)
}

\begin{abstract}
The oldest petroleum discoveries on the Brazilian offshore margin are in Paleogene reservoirs of the Guaricema and Dourado fields in the structural Mosqueiro Low, the Southern Sergipe-Alagoas Basin. Study of well logs and biostratigraphic data of the Eocene Series allowed its subdivision into three stratigraphic intervals representing the Ypresian, Lutetian-Bartonian, and Priabonian stages. The Ypresian depocenter is in the Dourado Trough, whereas the Lutetian-Bartonian and Priabonian depocenters are in the Vaza-Barris Trough, controlled by halokinesis in the first one and basement deformation in the others. The Ypresian interval mainly comprises retrogradational deposits related to the Early Eocene Climate Optimum. The Middle-Eocene Basal Unconformity is the main erosive feature in the Series. The Lutetian-Bartonian and Priabonian depositional systems are progradational. Their deposition is related to basement uplift due to both intense deep-water magmatism and to the Incaica Phase of the Andean Orogeny.
\end{abstract}

KEYWORDS: Brazilian offshore; gravity flows; halokinesis; basement deformation; paleogeography.

\section{INTRODUCTION}

The Eocene Epoch was a particular time in the Cenozoic Era in terms of tectonics and climate changes (Rona and Richardson 1978). Following the Paleocene-Eocene Thermal Maximum (PETM), a 200,000-year interval of extreme global warming marked the start of the Eocene Epoch about 55 million years ago, the Initial Eocene Thermal Maximum (Svensen et al. 2004) or Early Eocene Climate Optimum - EECO (Zachos et al.2001), related to the establishment of the North Atlantic Igneous Province. Tectonic activity was intense, with the initial formation of the Alpine-Himalayan Mountain Chain (Molnar 1986, Mutti et al. 1995, Ring et al. 2004, Sibuet et al. 2004) and strong deformation in the Andean orogen (Pardo-Casas and Molnar 1987), while Tasmania and Magalhães straits were opened, isolating Antarctica from Australia and South America (Kennett et al. 1977, Exon et al. 2004).

The Sergipe-Alagoas Basin, in Northeastern Brazil, is a narrow, NE-SW elongated depositional locus, $350 \mathrm{~km}$ long and $35 \mathrm{~km}$ wide, limited to the SW by the Vaza-Barris Fault and to the NE by the Maragogi High (Lana 1990). It is divided into the Sergipe and Alagoas sub-basins by the Japoatã-Penedo High (Fig. 1).

${ }^{1}$ Petrobras - Rio de Janeiro (RJ), Brazil. E-mails: criscrgeo@gmail.com, borba.claudio@yahoo.com.br

${ }^{2}$ Universidade Estadual Paulista "Júlio de Mesquita Filho" - Rio Claro (SP), Brazil. E-mail: davies.rose3@gmail.com

${ }^{3}$ Phoenix Foundation - Aracaju (SE), Brazil. E-mail: wagnerslima@ gmail.com

${ }^{*}$ Corresponding author.

(C) 2021 The authors. This is an open access article distributed under the terms of the Creative Commons license.
The Sergipe-Alagoas Basin has the most complete stratigraphic record of all divergent Brazilian offshore basins (Fig. 2). The Mosqueiro Low, a structural compartment in the Southern Sergipe Sub-basin, is recognized as the oldest offshore oil production area in Brazil. Petroleum occurs in Paleogene turbiditic reservoirs of the Calumbi Formation, Piaçabuçu Group (Feijó 1994). The study area is covered by more than 300 wells and by 3D seismic data. Nevertheless, little has been published on the area, and only Cainelli (1992) and Pedrão (2004) discussed stratigraphy, but neither provided detailed stratigraphy of the Eocene Series in the Mosqueiro Low.

Cainelli (1992) divided the Calumbi Formation into four sequences and emphasized the importance of the Eocene base unconformity as the main sequence boundary for this stratigraphic unit. Pedrão (2004) interpreted the Paleocene to Lower Eocene interval as predominantly transgressive. These interpretations are controversial.

In order to unravel this controversy, we have combined well logs and nannofossil biostratigraphic data to improve the stratigraphy of the Eocene Series in the Mosqueiro Low. A preliminary structural framework and a structural subdivision of this compartment have been constructed. Correlations allowed zoning of the Eocene Series that helps clarify such stratigraphic characteristics as depocenter distribution and the nature of sedimentary infill. Several features appear to be correlative to regional and global geologic events.

\section{GEOLOGICAL SETTINGS}

The stratigraphic record of the Sergipe-Alagoas Basin is divided into five super sequences (Fig. 2): Carboniferous 


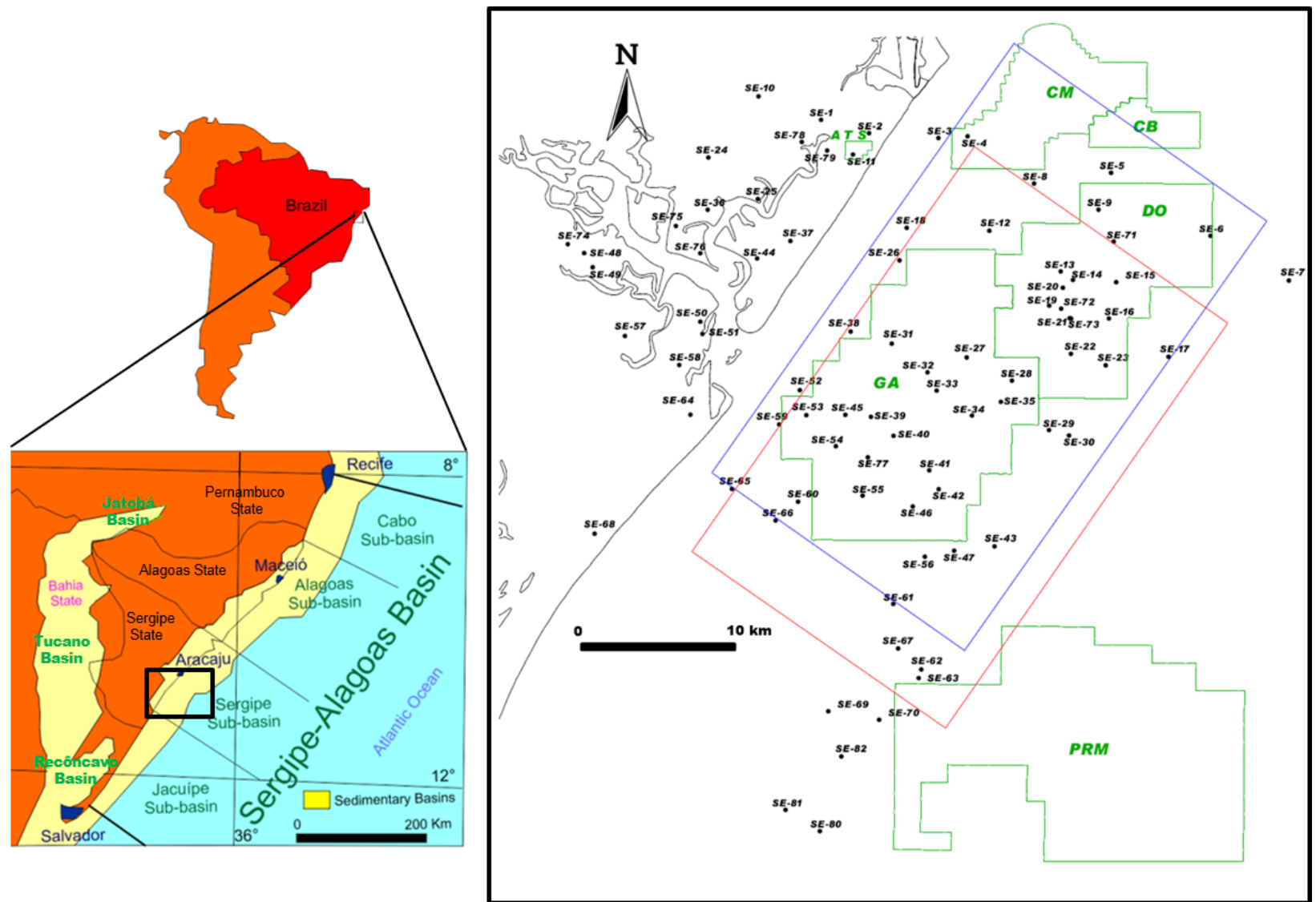

Figure 1. Location map of the Sergipe-Alagoas Basin, Northeastern Brazil (modified from Souza-Lima et al. 2002) and map of the study area in the Mosqueiro Low, the Southern Sergipe Sub-basin, Northeastern Brazil. Eighty-two wells were used in this work. Seismic data covering the area are in red and blue polygons. Also shown are the ring-fences of the Dourado (DO) and Guaricema (GA) fields, in Paleogene reservoirs, and the Piranema Field (PRM), in Campanian reservoirs.

to Permian Syneclisis, Tithonian to Berriasian Pre-rift, Berriasian to Lower Aptian Rift, Upper Aptian Post-rift, and Albian to Holocene Drift super sequences (Campos Neto et al. 2007).

The interval of interest in this study is the Drift Stage, which began during Early Albian, when a shallow calcareous platform was established. Fan-deltas were deposited along faulted borders, while limestones with ooids and oncoids were formed in highs, and calcilutites and shales were deposited in lows (Riachuelo Group). This calcareous platform was subsequently drowned by a transgression, when a mixed carbonatic to siliciclastic ramp was deposited, recorded by calcareous mudstones and shales (Coitinguiba Formation). Afterward, a regressive event resulted in the Sub-Calumbi Formation Unconformity, later covered by siliciclastic marine basin shales and deltaic to turbiditic deposits (Calumbi Formation), coastal sandstones (Marituba Formation), and bioclastic limestones (Mosqueiro Formation) of the Piaçabuçu Group. The sedimentation trend was transgressive between Santonian and Early Campanian, and subsequently, was mainly regressive.

Cainelli (1992) interpreted deep-water positive features of the Southern Sergipe-Alagoas Basin as igneous structures, which were also highlighted by Feijó (1994) and Mohriak et al. (1997). Campos Neto et al. (2007) recognized the presence of igneous rocks emplaced in Santonian-Campanian and Lower to Middle Eocene intervals.

\section{Structural framework of the Sergipe-Alagoas Basin}

The structural framework of the Sergipe-Alagoas Basin can be characterized by highs, steps, and lows (Fig. 3). Highs are sometimes wide areas, like platforms (such as Aracaju, Itaporanga, Estância, Japoatã, and Palmeira Alta) and sometimes very faulted and elongated (like in the Atalaia/Camorim, Siririzinho, and Penedo Highs). Steps are intermediary structures between highs and lows similar to asymmetrical ramps. The most important are the Vaza-Barris and Piranhas steps. Lows are asymmetrical negative features delimited at one side by large normal faults and the other by monoclines. The most important lows are associated with the hinge line fault system, as the Mosqueiro and São Francisco lows. Other important negative structures are in Santa Rosa de Lima, Divina Pastora, and Japaratuba lows, located in the onshore area.

The structural development of the Sergipe-Alagoas Basin based on onshore and shallow water data was conceived by Chagas (1996) as a four-phase monocyclic polyphasic deformation model. The first phase, which occurred between Hauterivian and Barremian ages, was defined by an E-W extension, with main depocenters concentrated next to N-S faults and accommodated by E-W transfer faults. The second phase, which took place between Barremian and Middle Aptian times, was defined by a NW-SE extension, with main depocenters concentrated near the NE-SW faults created during this phase. The deformation was accommodated by the NW-SE transfer faults. This stress field continued during two more phases, in Middle Aptian to Albian and Early to Late Albian. 


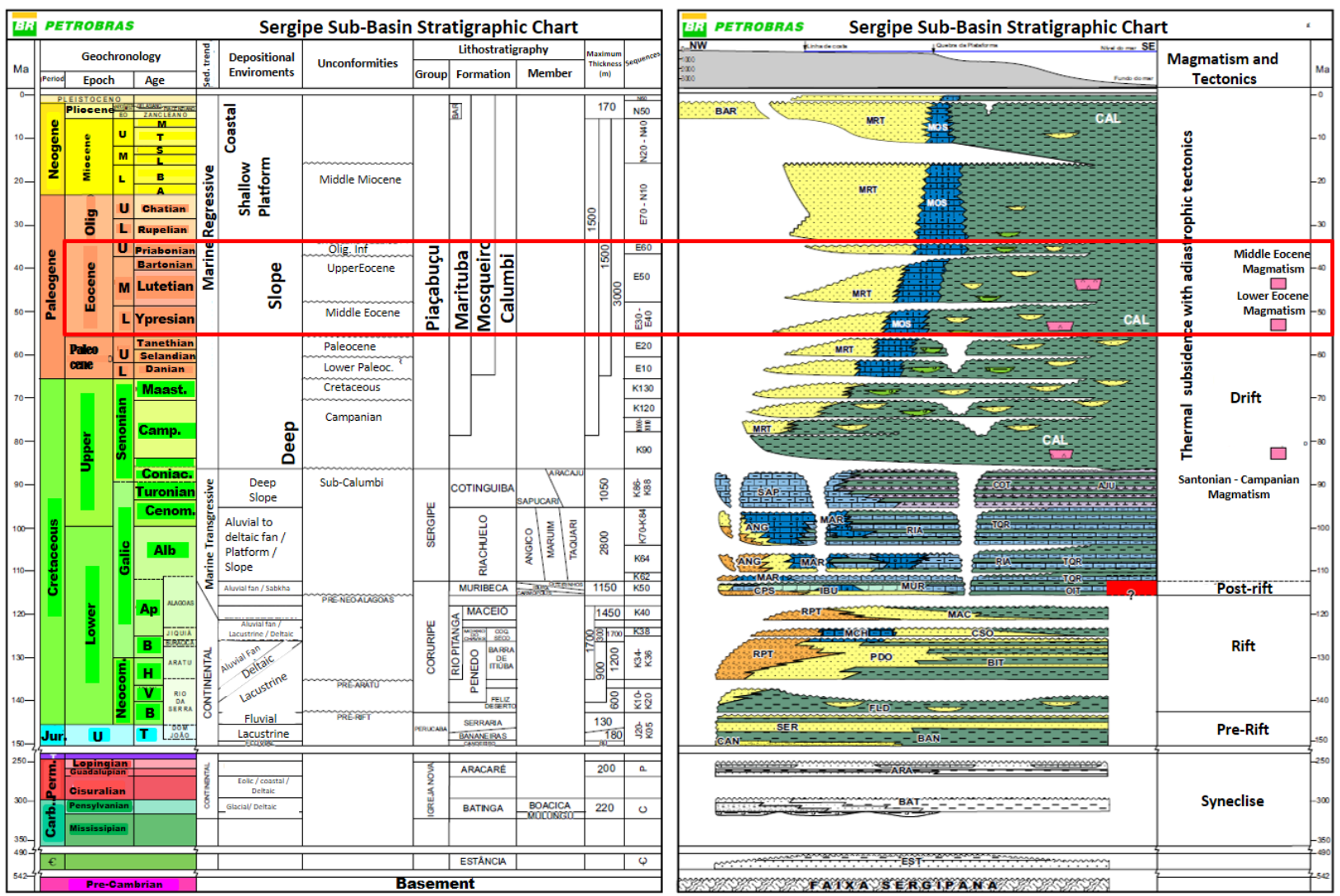

Figure 2. Sergipe Sub-basin Stratigraphic Chart (modified from Campos Neto et al. 2007), highlighting the Eocene Series and the magmatism associated with it.

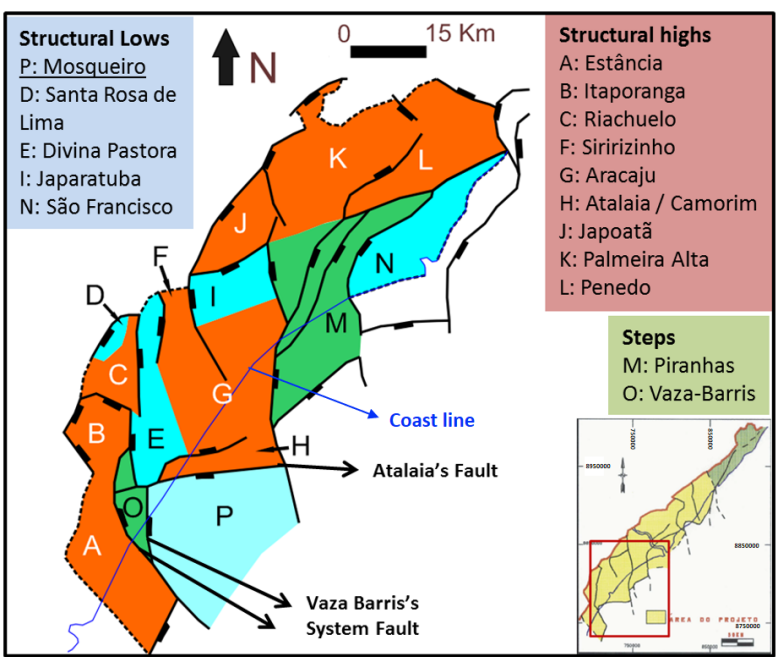

Source: modified from Chagas (1996).

Figure 3. Structural compartmentalization of the Sergipe-Alagoas Basin, with the Mosqueiro Low compartment $(\mathrm{P})$ and its bordering faults.

The Mosqueiro Low structural compartment (Fig. 3), which is the object of this study, is positioned at the Southern portion of the Sergipe-Alagoas Basin, limited to the North by the Atalaia Fault (with the Atalaia High), and to the West and South by the Vaza-Barris Fault System (with the Vaza-Barris Step and Estância Platform - EP).

\section{Stratigraphy of Piaçabuçu Group}

This topic is a historical review of Piaçabuçu Group and its subdivisions (Marituba, Mosqueiro, and Calumbi formations), all of which are covered by this paper (Fig. 2). The informal
Calumbi unit was firstly introduced by Duarte (1936) to describe muddy limestones interbedded with sandstones in outcrops near Aracaju City (Sergipe State). Bender (1957) applied the same definition to describe green olive shales interbedded with lime mudstones and fine sandstones, referred to as the informal Calumbi formation unit (on those days, a stratigraphic code had not not been followed yet). Ruefli (1963) introduced the Piaçabuçu informal unit to define an assembly of Mosqueiro Limestone (calcarenites), Lower Tertiary (coarse to medium sandstones and conglomerates), and Calumbi Shale formation informal units, individualized as a particular interval on well logs. Schaller (1970) characterized the green shales with occasional lenticular sandstones as deposits of the formal Piaçabuçu Formation, divided into the Calumbi Member (shales and mudstones rarely interbedded with sandstones) and the Marituba Member (coarse to medium sandstones and conglomerates interbedded with calcarenites). These sandstones were mainly deposited by sediment gravity flows as submarine fans near the slope base (Ponte et al. 1975), but coastal and shallow platform deposits were also described (Souza-Lima 2001). Lana (1990) illustrated exploratory targets of the Piaçabuçu Formation related to Paleocene and Eocene reservoirs of the Guaricema and Dourado fields. Using basin-scale seismic data, Cainelli (1992) divided the Piaçabuçu Formation into four sequences: Upper Cretaceous, Paleocene, Eocene, and Oligo-Neogene. They also highlighted the base of Eocene unconformity as the main sequence boundary for this stratigraphic unit. Feijó (1994) reviewed the Sergipe-Alagoas Basin stratigraphy and upgraded Piaçabuçu Formation to group status, which was 
then divided into the Calumbi, Marituba, and Mosqueiro formations. Pedrão (2004) proposed a biostratigraphic subdivision for the Paleocene-Eocene interval based on palynomorphs, isotopes, and log data, and interpreted the Paleocene to Lower Eocene as an interval of predominant transgressive conditions (with the maximum flooding surface at the N-410 biozone level), while the Middle to Upper Eocene presented evidence of largely regressive conditions. Quadros et al. (2015) suggested bathyal to neritic conditions for the Mosqueiro Low in the Middle Eocene based on foraminifera and palynomorph data.

\section{MATERIAL AND METHODS}

Eighty-two wells were selected from a dense set of wells in the Mosqueiro Low, based on logs and biostratigraphic data coverage of the Eocene Series (Fig. 1).

The nannofossil biostratigraphic zoning was extracted from Petrobras database. The top of biozones is defined by the first occurrence of a key form or association through analyses in cutting samples, from the surface to the bottom in each well (Antunes and Melo 2001). This first occurrence is often related to the position of a stratigraphic surface with regional significance (unconformities, maximum flooding surfaces) or as a response to local changes. When defined in response to local changes, a common aspect in the geological record, the position of the biozone top does not coincide with the top of the chronostratigraphic unit. In this case, an association between well logs and seismic data might help to define the correct top position of the chronostratigraphic unit.

The Gamma Rays log is often interpreted in terms of sediment grading (fining versus coarsening upward), while the sonic log is related to porosity and cementation (Catuneanu 2006). The resistivity log reflects fluid content and pore space; values of resistivity decrease inversely to pore space (Prothero and Shwab 1996). Trends on well logs are a function of sedimentation and diagenesis, and changes in these trends can be related to stratigraphic surfaces. Breaks on trends of gamma ray, resistivity, and sonic logs coupled with nannofossil zones were combined to divide the Eocene in Lower (Ypresian), Middle (Lutetian-Bartonian), and Upper (Priabonian) intervals for each well. Sigeo Software, from Petrobras, was used to carry out this task.

According to Antunes et al. (2004), the base of the Ypresian (Lower Eocene) was established near the top of the N-350 biozone; the base of the Lutetian (Middle Eocene), near the top of the N-430 biozone; the base of the Priabonian (Upper Eocene), near the top of the N-450 biozone; and the top of Eocene, near the top of N-470 biozone (Fig. 4).

The 82 wells were correlated along geologic and stratigraphic sections to ensure reliable interpretation, and geologic sections were drawn with the additional support of seismic data. The integrated data were gridded by the least square method, in $100 \times 100$ meters cells, and thus structural maps of the base of Ypresian, Lutetian, Priabonian and Oligocene were produced. Subtraction operations between them were performed in order to provide isopach maps of the Lower, Middle,

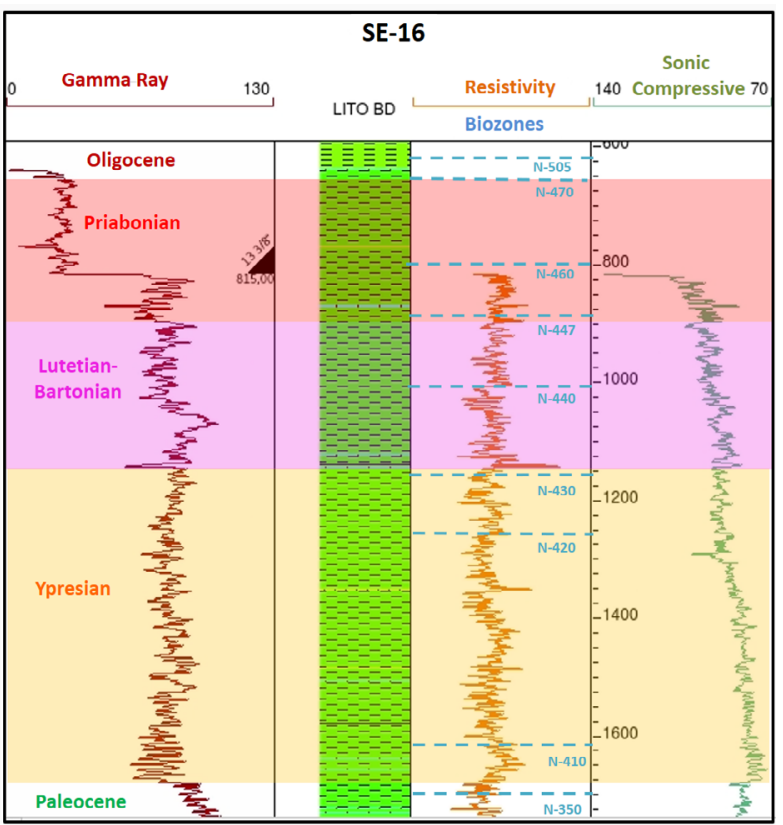

Figure 4. Example of stratigraphic zoning for the Eocene Series in SE-16 well. From left to right, Gamma Ray log (API) is on track 1 (horizontal lines indicate interpreted breaks on trends), lithological profile is on track 2. Resistivity log (ohm.m) and the original position of biozones are on track 3 , and p-wave (milliseconds/ft) sonic $\log$ is on track 4 .

and Upper Eocene horizons. Integration of rock descriptions (from cuttings) for each sequence was undertaken to yield isolith maps. An internal subdivision of the Mosqueiro Low was proposed based on these maps and sections.

A genetic stratigraphic framework was built with 12 wells based on the method proposed by Catuneanu et al. (2001). The sequence boundaries are associated with the basal surfaces of forced regression or type 1 correlative conformity (Posamentier and Allen 1999). Each sequence was, in turn, divided into different system tracts: lowstand system tract (LSST), which is limited at the top by a maximum regressive surface (Catuneanu 1996, Helland-Hansen and Martinsen 1996); transgressive system tract (TST), which is limited at the top by a maximum flooding surface (Frazier 1974, Posamentier and Vail 1988); and highstand system tract (HSST), which is limited at the top by type 1 correlative conformity. The limits of the sequences are marked by breaks in log trends, especially p-wave sonic, and by intervals with a lack of section. Maximum regressive surfaces were marked at the inflection of the gamma ray profile, in which radioactivity changes from decreasing to increasing towards the top and represents the last deposition of progradational deposits in the LSST. Maximum flooding surfaces were marked at a positive peak of the gamma rays log, near the inflection where radioactivity changes from increasing to decreasing towards the top, ending a drowning tendency, and representing radioactive shales. Near this surface, it is common to observe negative gamma ray peaks, which can be nannofossil chalks in condensed sections.

Block diagrams summarize integration of all of the interpretation data. 


\section{RESULTS}

\section{Structural characteristics}

Structural maps derived from interpretations of well markers were made for four structural surfaces, namely the base of the Ypresian, Lutetian, Priabonian, and Oligocene (Fig. 5). The curviplanar features on the maps correspond to faults.

A detailed zoning of the Eocene Series in the Mosqueiro Low allowed the individualization of structural features identified as plateaus (similar to highs), steps, and troughs (similar to lows). Plateaus are flat features with limited ramps, sometimes resulting from the filling of previous mini-basins. Steps correspond to negative features structured by two sequenced half-grabens, and troughs are larger negative features, controlled by normal faults. These features migrated over time driven by deformation and sedimentation.

The structural framework of the area has NE-SW, NW-SE, and N-S trending faults (Fig. 3). N-S faults are restricted to the Dourado Trough - DT (Fig. 5). NE-SW faults structured mini-basins related to salt diapir that captured sediments throughout the entire area, most importantly in the Dourado Step (DS) and Guaricema Trough - GT (Figs. 6A and 7A). The rare NE-SW faults with NW-dip, therefore antithetical, are associated with halokinesis in the Northern Step - NS (Fig. 6B). The NW-SE faults controlled the occurrence of the Middle Eocene section in the Western sector of the area, along the Ilha de Mem de Sá Trough (IMST), and in the Northern sector, along Atalaia Sul Channel - ASC (Fig. 6A). These features are separated by the Mosqueiro Plateau (MP), a positive feature on which the Ypresian section is almost absent.

In addition to these troughs, NW-SE faults, dipping mainly to NE and secondarily to SW, structured the Vaza-Barris Trough (VBT), along the homonymous fault system with subordinate NE-SW trend (Figs. 7A and 7B). Deformation along this fault system conditioned the VBT as a depositional site during the Ypresian, but the deep erosion profile of the Middle Basal Eocene Unconformity removed this section (Figs. 5A and 7A). The IMST can represent the extension of VBT to NW,
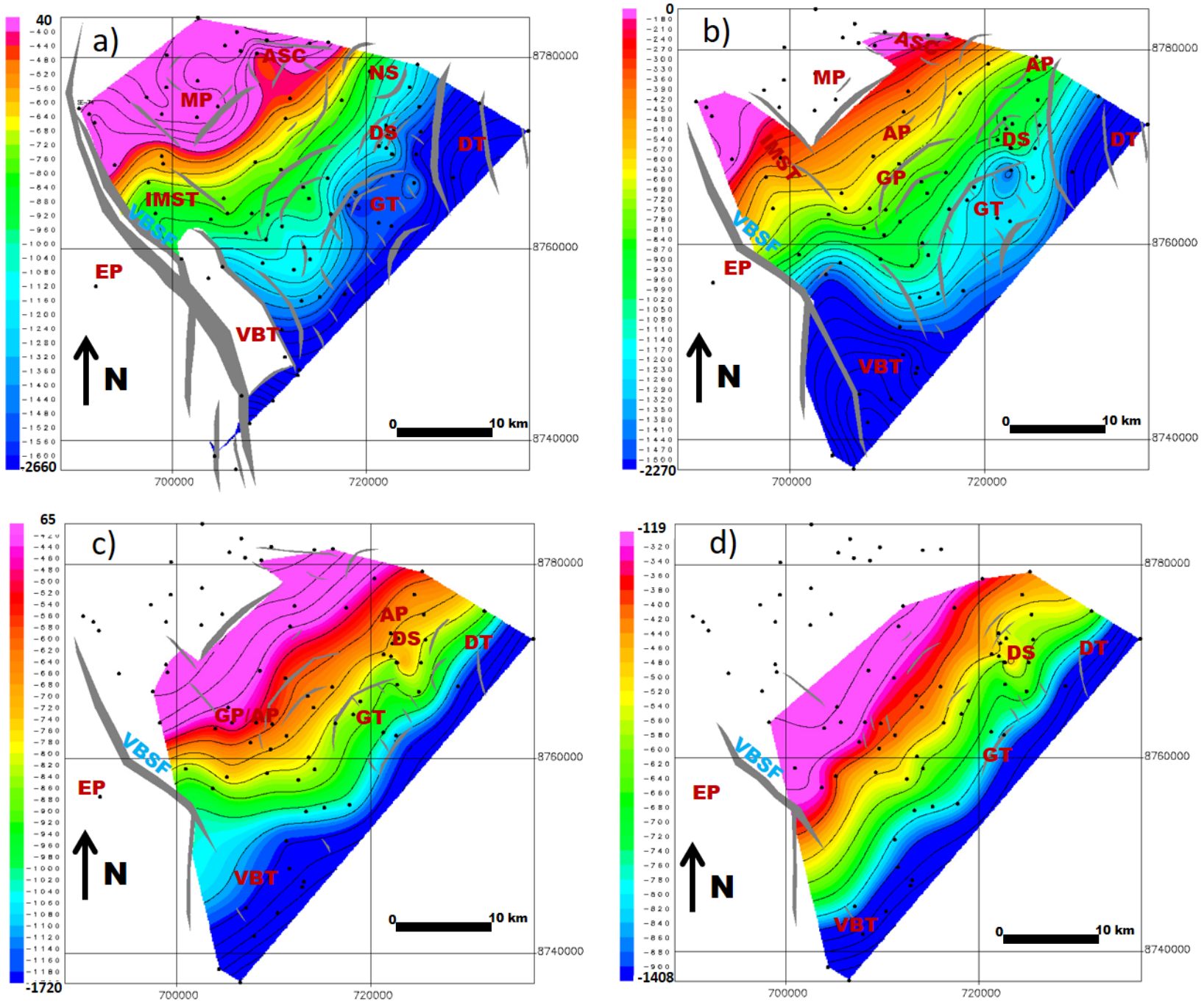

EP: Estância Platform; VBSF: Vaza-Barris System Fault; IMST: Ilha de Mem de Sá Trough; VBT: Vaza-Barris Trough; GT: Guaricema Trough; NS: Northern Step; ASC: Atalaia Sul Channel; MP: Mosqueiro Plateau; GP: Guaricema Plateau; DS: Dourado Step; DT: Dourado Trough; AP: Atalaia Platform.

Figure 5. Structural maps in depth (m) of the unconformities of the base of the (A) Lower Eocene, (B) Middle Eocene, (C) Upper Eocene, and (D) Oligocene with contour intervals of 100 meters. The sequence shows paleophysiography changes and landscape evolution due to sedimentation and deformation. Higher areas are in pink, red and yellow, and lower areas in blue and green. Curviplanar features in gray correspond to faults that cross the structural surface. Dots represent the position of the wells (compare with Figure 4). 

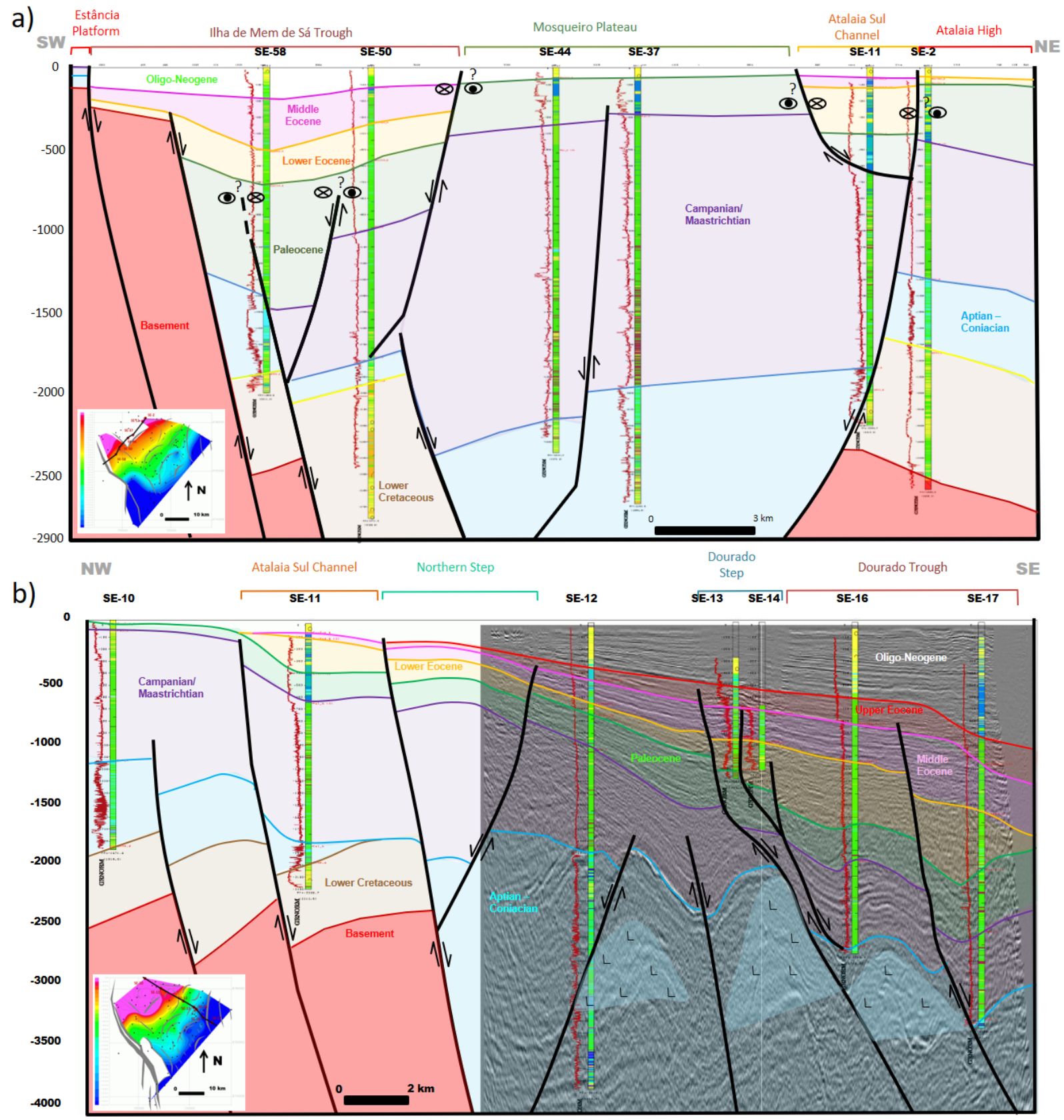

Figure 6. (A) SW-NE geologic section (m) from the Estância Platform to the Atalaia High. In the Western area (upstream of depositional systems), the occurrence of Middle Eocene rocks is controlled by faults. Lower Eocene rocks are thicker in the Atalaia Sul Channel and the Ilha de Men de Sá Trough. Section location in inset with a structural map of base of the Lower Eocene: shading from blue (deeper) to red (shallower). (B) NW-SE geologic section (m) from the Atalaia Sul Channel to the Dourado Trough. Halokinesis controls sediment sites of the Dourado Step and Trough. Inset with a structural map of base of the Lower Eocene: shading from blue (deeper) to red (shallower).

separated from each other by a fault with slumps and debris flows deposited directly on the basement.

\section{Depocenters and sedimentary filling}

Depocenters were characterized, and the nature of the sedimentary filling was identified by analyzing isopach maps (Fig. 8), and sandstones (Fig. 9), and limestones (Fig. 10) isolith maps. The area was dominated by muddy sediments along the whole Eocene Series.

The main Lower Eocene depocenter is located in the DT, which gets over $500 \mathrm{~m}$ thick (Fig. 8A), as an extension of the DS (with $400 \mathrm{~m}$ ). In this trough, sandstones reached $30 \mathrm{~m}$ (Fig. 9A), while limestones reached $70 \mathrm{~m}$ in thickness
(Fig. 10A). At NW of these features, the ASC (Fig. 6A) represents the updip site of sedimentation, with $300 \mathrm{~m}$ of mixed filling, predominantly carbonate (around $180 \mathrm{~m}$ ), with a subordinate occurrence of sandstones (about $60 \mathrm{~m}$ ). The IMST was also an important site of sedimentation, where the sedimentary section reached about $300 \mathrm{~m}$. Sedimentary content is mostly muddy, with some sandstone about $30 \mathrm{~m}$ thick (Fig. 6A).

In the Middle Eocene, the depocenter migrated to VBT, where thicknesses reached more than $800 \mathrm{~m}$ (Fig. 8B). In this feature, the Lutetian basal unconformity eliminated much of the Ypresian section and placed the Middle Eocene section in direct contact with the Paleocene and sometimes even with the Coniacian section (Fig. 7A). 
a)
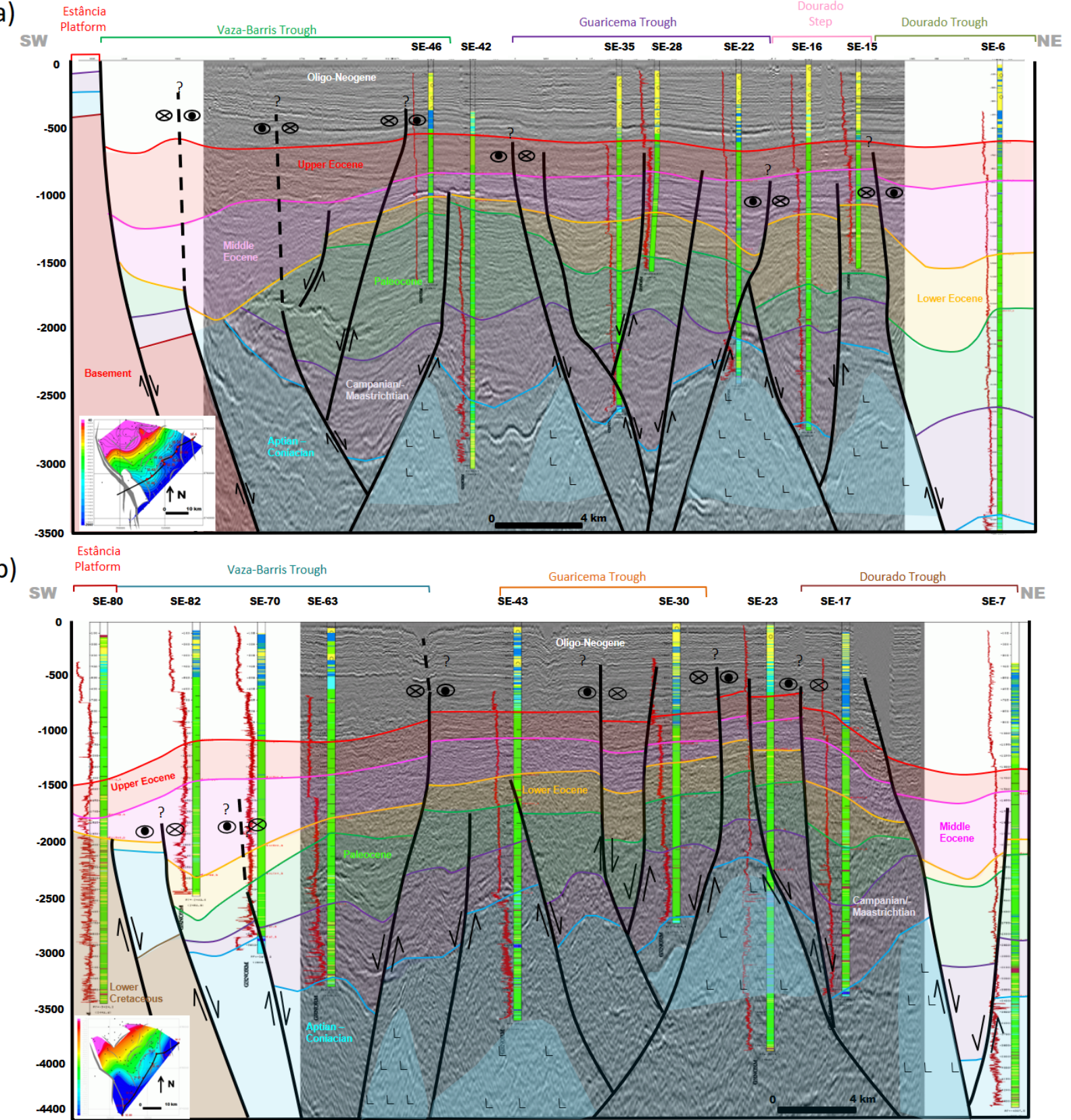

Figure 7. (A) SW-NE geologic section (m) from the Estância Platform to the Dourado Trough. Halokinesis controls sediment sites of the Dourado Step and the Dourado Trough, and also the Guaricema Trough. Basement deformation is important in the Vaza-Barris Trough. Section location in inset with a structural map of base of the Lower Eocene: shading from blue (deeper) to red (shallower). (B) SW-NE geologic section $(\mathrm{m})$ from the Estância Platform to the Dourado Trough. Halokinesis controls sediment sites of the Dourado and Guaricema troughs. Deformation on Lower Cretaceous rocks is important in the Western flank of the Vaza-Barris Trough. Section location in inset with a structural map of base of the Lower Eocene: shading from blue (deeper) to red (shallower).

To the W-SW, the sedimentary interval pinches out against the EP along the Vaza-Barris Fault System, above rocks of the Rift Supersequence (Fig. 7B). It is also in this depression that the sandstones are thicker, up to $130 \mathrm{~m}$ thick (Fig. 9B). The IMST was reduced in area and migrated downdip, where the sandstones attained a thickness of $40 \mathrm{~m}$. During the Mesoeocene, sedimentation filled the border between the IMST and VBT, which started acting like the same compartment. In the DT and GT, there was thickening of the Middle Eocene section to over $500 \mathrm{~m}$, with sandstones up to $30 \mathrm{~m}$ thick in the former, and mud in the latter. Nestled between the IMST and the MP, the Guaricema Plateau (GP) was a local site of mixed sedimentation, where siliciclastic and carbonate sandstones that are $100 \mathrm{~m}$ thick are found (Figs. 9B and 10B).

Three main sites of sedimentation are defined for the Upper Eocene: the Vaza-Barris, Guaricema, and DT (Fig. 8C). There is no record of this stage in ASC, and what once was the IMST became part of the Northern section of the VBT. The depocenter is again located in the VBT, but updip from the Middle Eocene depocenter, where its thickness reaches about $700 \mathrm{~m}$ (Fig. 8C). In the DT, the section comprises about $300 \mathrm{~m}$, but it thins downdip due to the erosive surface that delimits the top of the Eocene, which restricts the trough area compared to the previous depocenter (compare Figures $8 \mathrm{~B}$ and $8 \mathrm{C}$, and see Figure $6 \mathrm{~B}$ ). In the GT, the section is $300 \mathrm{~m}$ thick, controlled 

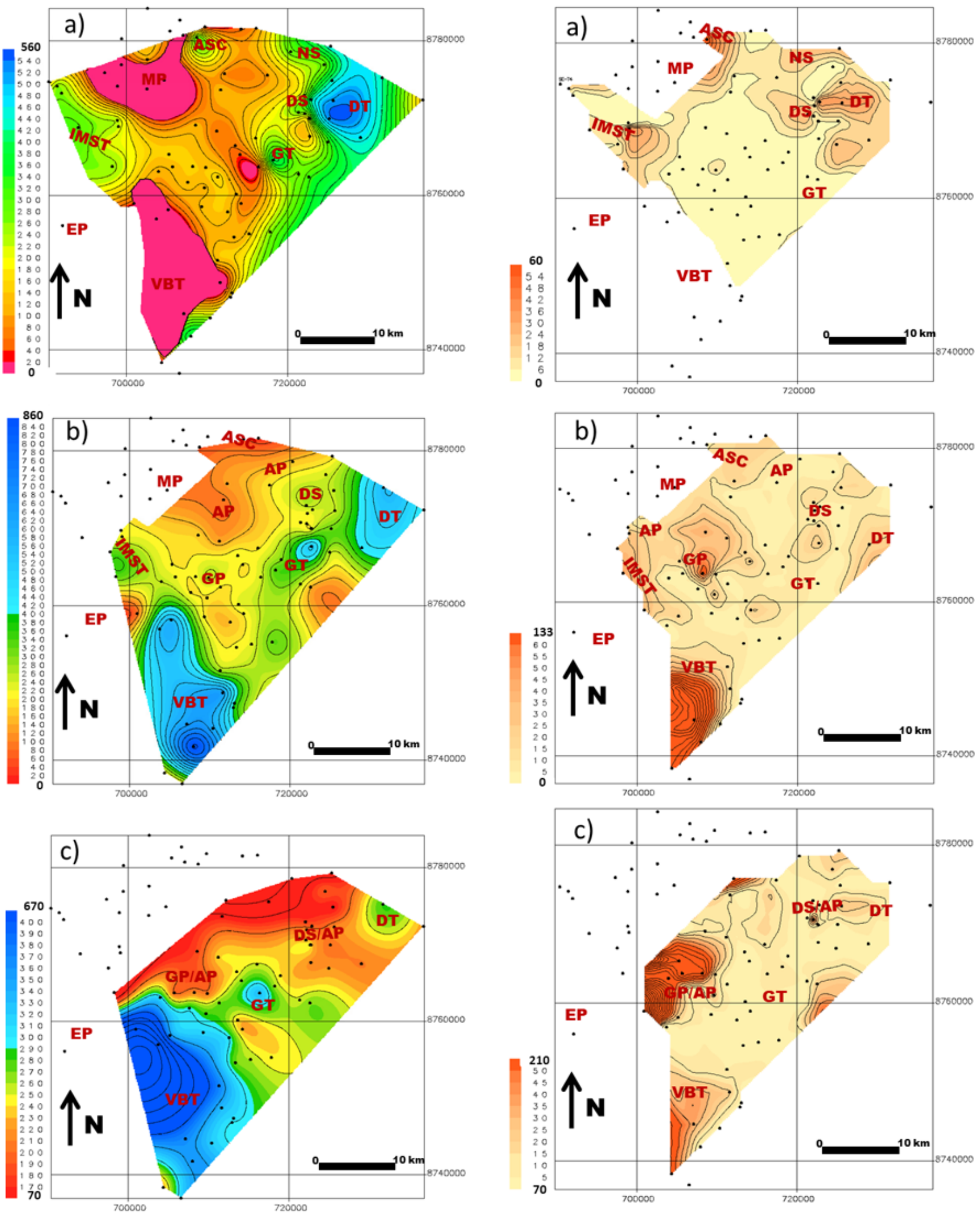

EP: Estância Platform; VBSF; Vaza-Barris System Fault; IMST: Ilha de Mem de Sá Trough; VBT: Vaza-Barris Trough; GT: Guaricema Trough; NS: Northern Step; ASC: Atalaia Sul Channel; MP: Mosqueiro Plateau; GP: Guaricema Plateau; DS: Dourado Step; DT: Dourado Trough; AP: Atalaia Platform.

Figure 8. Isopach maps (in meters) of: (A) Lower Eocene (contour interval $=30 \mathrm{~m}$ ), (B) Middle Eocene (contour interval $=50 \mathrm{~m})$, (C) Upper Eocene (contour interval = $50 \mathrm{~m}$ ). The sequence shows landscape evolution due to sedimentation and deformation. Thinner areas are in red, orange and yellow, and thicker areas in blue and green. Dots represent the position of the wells (compare with Figure 2).

EP: Estância Platform; VBSF; Vaza-Barris System Fault; IMST: Ilha de Mem de Sá Trough; VBT: Vaza-Barris Trough; GT: Guaricema Trough; NS: Northern Step; ASC: Atalaia Sul Channel; MP: Mosqueiro Plateau; GP: Guaricema Plateau; DS: Dourado Step; DT: Dourado Trough; AP: Atalaia Platform.

Figure 9. Sandstone isolith maps (in meters) of: (A) Lower Eocene (contour interval $=6 \mathrm{~m}$ ), (B) Middle Eocene (contour interval $=10 \mathrm{~m}$ ), (C) Upper Eocene (contour interval $=10 \mathrm{~m}$ ). The sequence shows sandstone depocenter changes. Thicker areas in orange and thinner areas in yellow. Dots represent the position of the wells (compare with Figure 2). 

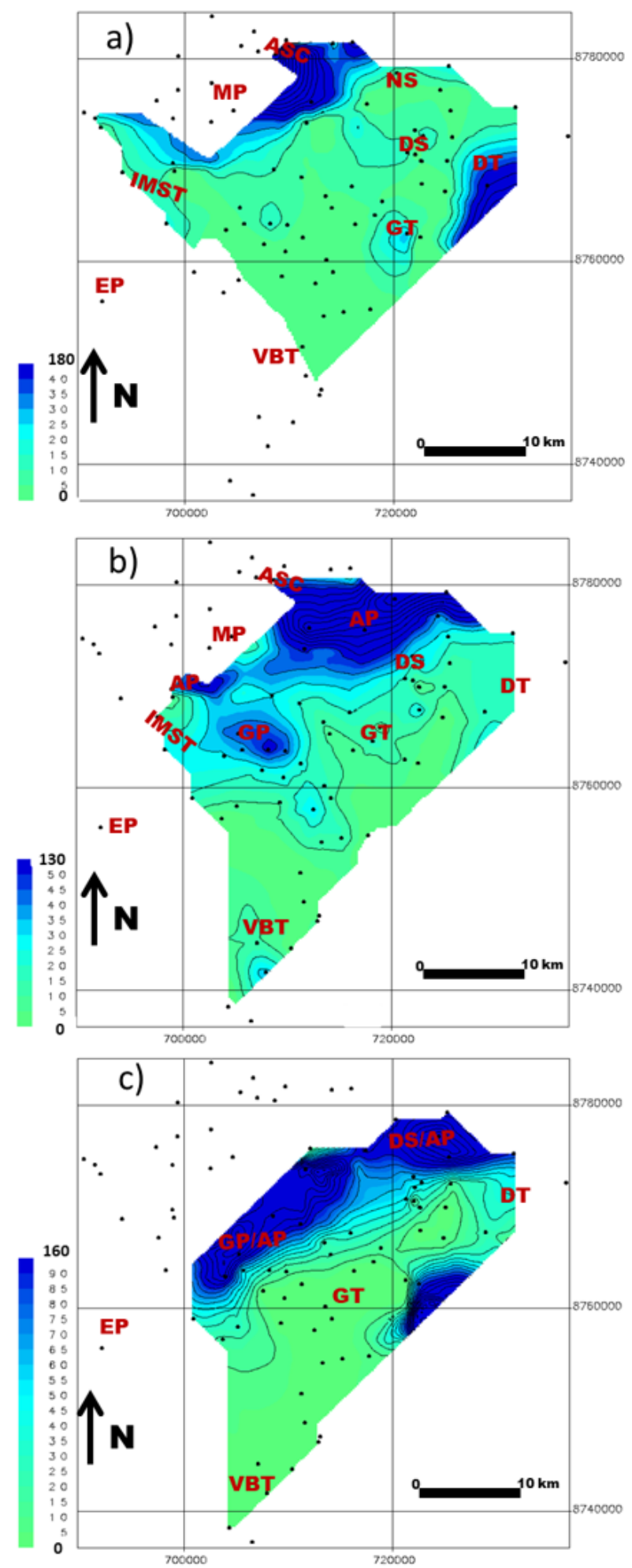

EP: Estância Platform; VBSF; Vaza-Barris System Fault; IMST: Ilha de Mem de Sá Trough; VBT: Vaza-Barris Trough; GT: Guaricema Trough; NS: Northern Step; ASC: Atalaia Sul Channel; MP: Mosqueiro Plateau; GP: Guaricema Plateau; DS: Dourado Step; DT: Dourado Trough; AP: Atalaia Platform.

Figure 10. Limestone isolith maps (contour interval $=10$ meters) of: (A) Lower Eocene, (B) Middle Eocene, (C) Upper Eocene. The sequence shows carbonate platform migration to SE. Thicker areas in blue and thinner areas in green. Dots represent the position of the wells (compare with Figure 2).

by fault. The sandstones were concentrated in the GP, with a thickness of $100 \mathrm{~m}$ (Fig. 8C), and in the Northern VBT, where it is around $60 \mathrm{~m}$ thick. The carbonate fabric was distributed along the vicinities of the DT and the GP, in a NE-SW trending continuous feature (Fig. 10C). There was significant carbonate content at the Southern GT, where the maximum thickness of the preserved deposits reached $160 \mathrm{~m}$.

\section{Paleogeography and genetic stratigraphy}

The paleogeography of the Eocene Epoch is illustrated on block diagrams based on structural, isopach, and isolith maps, and also on geologic and stratigraphic sections. In addition to interpretative abstractions of basin paleophysiography in each time interval, blocks include downdip and updip interpreted information on stratigraphic sections that were later eroded (compare maps of Figure 5 with block diagrams). Stratigraphic sections illustrate the main genetic features interpreted.

\section{Ypresian (Early Eocene)}

During the Early Eocene (Fig. 11A), the EP and the MP, $\mathrm{W}$ and $\mathrm{N}$ of the Mosqueiro Low, respectively, were dominated by coastal to neritic siliciclastic systems. The EP was a relative structural high of the Precambrian basement, while the MP was a siliciclastic platform with isolated carbonate bioaccumulated mounds. These mounds were intersected by the ASC, a trough that initially trapped siliciclastic and carbonate sediments from the platform and then acted as a sediment bypass zone downdip. Downdip, the ASC fed the DS, the NS, and the DT, three intraslope mini-basins (the third one larger in area), respectively controlled by NE-SW and N-S halokinesis-related faults (Fig. 5). These mini-basins were filled by deltaic and turbidite siliciclastic to carbonate systems. The DS and NS have initially acted as a bypass zone towards the DT, when siliciclastic influx was more intense, and then changed to a depositional zone, with sedimentation of smaller sandy lobes fed along the axial fault plane. The ASC also supplied sediments downdip to the GT, another intraslope halokinesis-related mini-basin, but with essentially carbonate sand lobes. The Vaza Barris System Fault (VBSF) has controlled two important structural lows: the IMST and the VBT, limited by slump deposits on a relative structural basement high. The IMST has captured a considerable amount of sand from $\mathrm{NW}$, but the main sediment influx came from the EP. The VBT had a more complex structural behavior, with a step at SSW as an area for sandy sediment influx. Debris flows and slumps from NW filled the VBT downdip. The erosion profile of the basal unconformity for this interval, linked to subsidence at the VBSF, allowed locally Ypresian sediments to rest directly on the basement. The Ypresian interval was a stage dominated by muddy sediments, with a depocenter at the DT, fed by the ASC along the DS.

The stratigraphic section flattened on the maximum flooding surface of the Lower Eocene (Fig. 12A) illustrates gravity flow deposits in clinoforms, concentrated in the DT, as genetic deposits of regression in a LSST. They were followed by retrogradational deposits of shales, interbedded with sandstones in the DS, with a maximum flooding surface at the $\mathrm{N}-420$ biozone level. This surface represents a large drowning started in the Paleocene as a maximum flooding surface (Fig. 13). The genetic deposits of normal regression in highstand system tract were partially eroded by the Middle Eocene basal unconformity. 


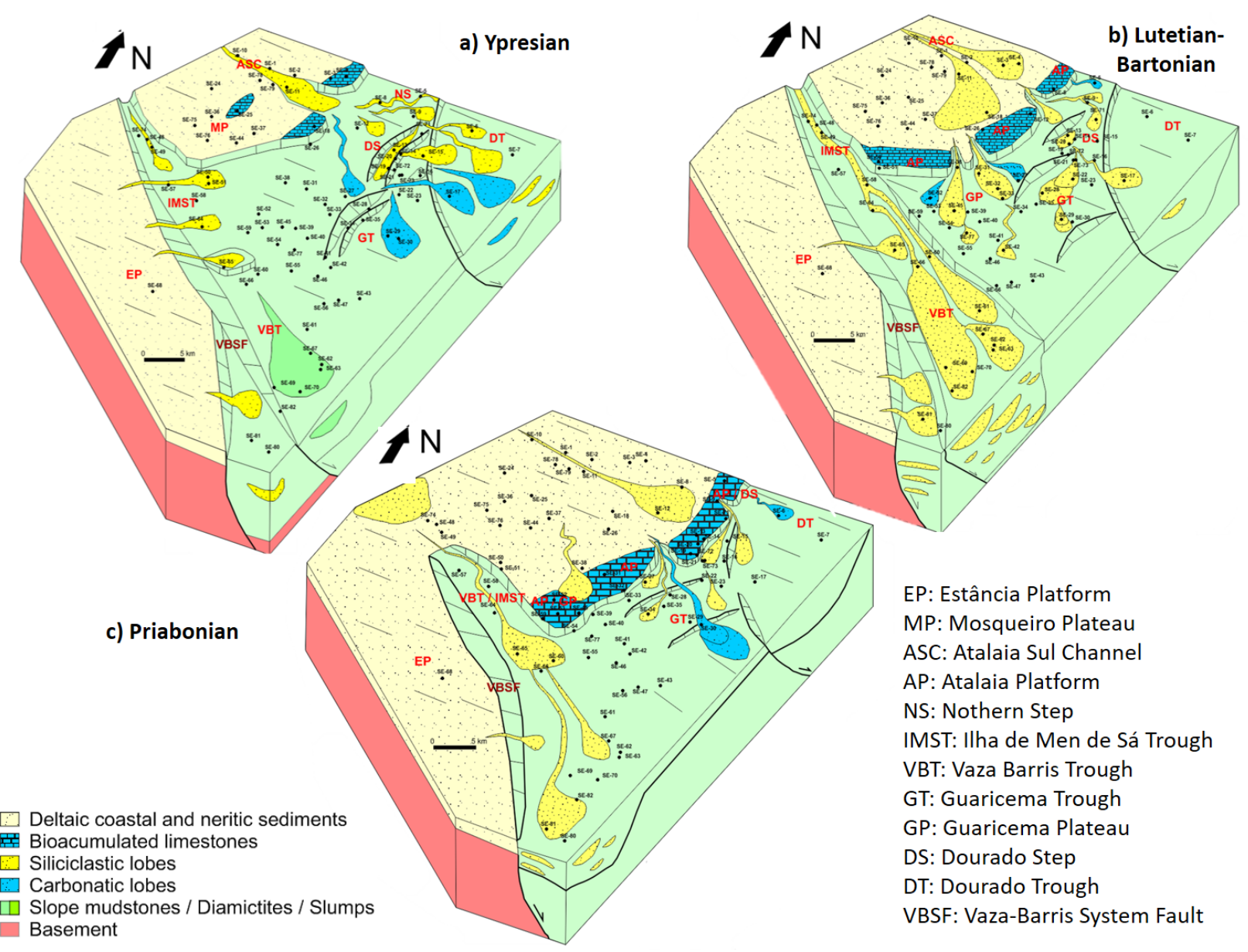

Figure 11. Blocks diagram of the paleogeography and sedimentary depositional systems compiled for the (A) Ypresian (Early Eocene), (B) Lutetian - Bartonian (Middle Eocene), and (C) Priabonian (Late Eocene).

\section{Lutetian to Bartonian (Middle Eocene)}

There were expressive changes in the Mosqueiro Low paleophysiography during the Middle Eocene (Fig. 11B). The ASC was still a bypass zone of deltaic systems towards the DS and DT, but lost expression as an important depositional site. The DS was supplied by siliciclastic sand along relay ramps. The DT was almost starved, with low content of sandy sediments. Downdip of the MP, bioaccumulated limestones built the first Eocene carbonate platform, named the Atalaia Platform (AP) in this paper, interbedded with coastal siliciclastic sediments and crosscut by deltaic and turbidite systems at the slope area. The low gradient area between the IMST and GT, named GP in this paper, was a depositional site not only for carbonate lobes of the AP, but also for siliciclastic lobes derived from proximal areas. The IMST also changed from a depositional site to a bypass zone downdip to the VBT. Along this latter trough, updip braided channeled features lost their confinement to the Southeast, where the flow increased and extensive sandstone lobes were deposited, representing an important siliciclastic sandy influx on the basin. The main conduits for sediment transfer were NW, updip from the VBT, with an important siliciclastic source from $\mathrm{W}$ (EP) controlled by the VBSF. The VBT was deeper than it was in the Ypresian, with erosion of previously deposited sediments induced by the main deformation phase of the Cenozoic Era in the Mosqueiro
Low. Sand bodies were deposited in thickening upward parasequences related to progradational trends of deltaic and turbiditic systems. The limits between the IMST and VBT were eliminated by sedimentation. The Middle Eocene paleogeography is marked by the expressive occurrence of siliciclastic and carbonate sandy deposits that constituted a system progradation that advanced farther downdip when compared with its limit during the Ypresian.

The stratigraphic section flattened on the maximum flooding surface of the Middle Eocene (Fig. 12B) illustrates the erosive behavior of the Middle Eocene Unconformity, which removed Lower Eocene deposits downdip and cut horizons as deep as the Coniacian, implying expressive section absence. The genetic deposits of regression in LSST have expressive sandy content and initial thickening of layers in clinoforms and are concentrated in the VBT. They were followed by transgressive deposits, also with the occurrence of sandstones and maximum flooding surface at the N-447 biozone level. The Upper Eocene basal unconformity eroded much of the regressive highstand deposits.

\section{Priabonian (Late Eocene)}

Priabonian was the weakest syn-sedimentary deformation interval of the Eocene and also the time of main buildup and expansion of the carbonate platform (AP, Fig. 11C). The AP migrated downdip to the GP and DS, where an effective physical 

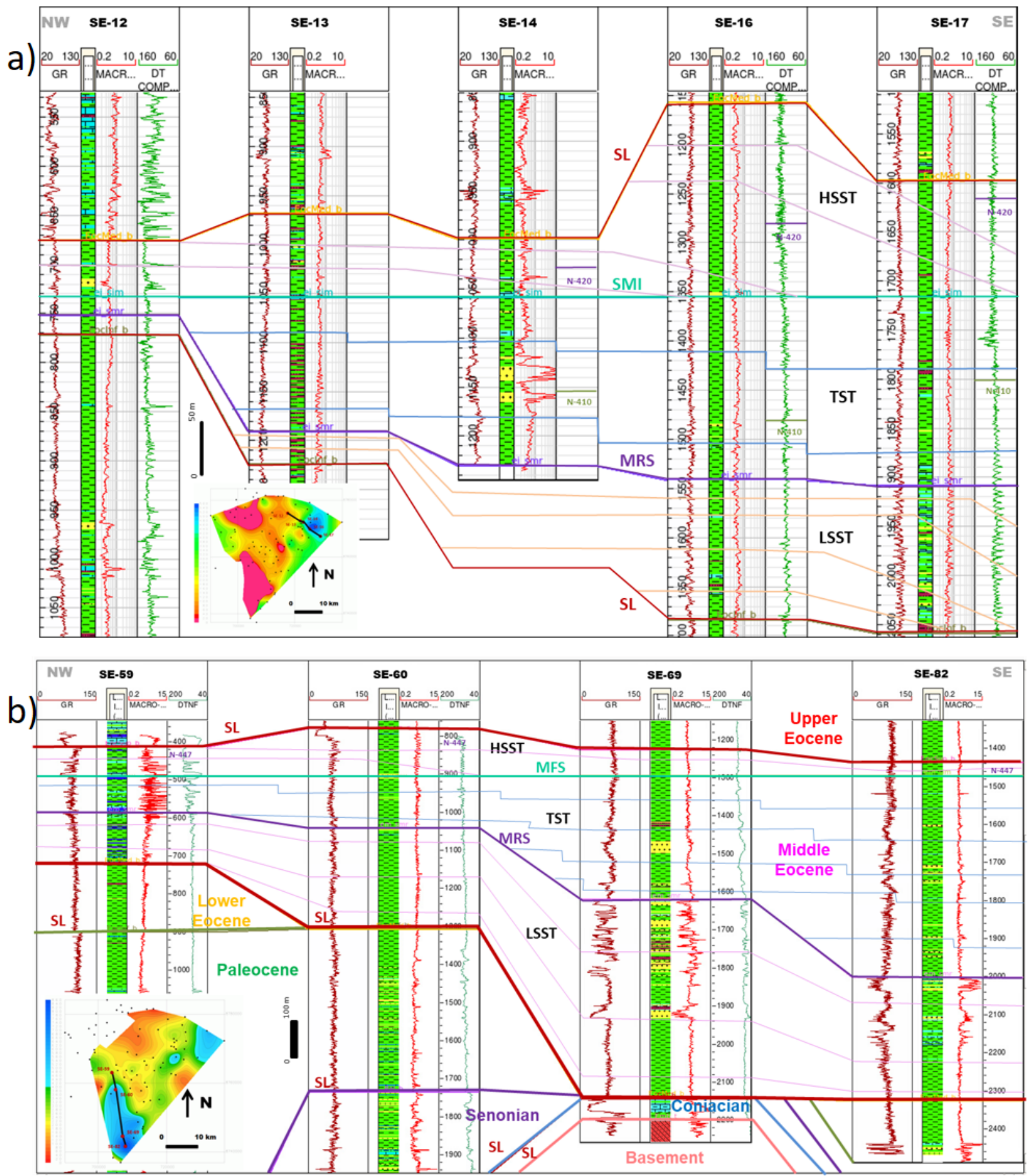

SL: Sequence Limit; LSST: Lowstand System Tract; TST: Transgressive System Tract; HSST: Highstand System Tract; MRS: Maximum Regressive Surface; MFS: Maximum Flooding Surface.

Figure 12. (A) Stratigraphic section flattened at the Lower Eocene maximum flooding surface. Gravity flows of regression on lowstand concentrated in the Dourado Trough (SE-16 and SE-17). Sandstones in transgressive system deposit on the Dourado Step (SE-14), with a maximum flooding surface at the N-420 level. Section location on the inset with the Lower Eocene isopach map (blue thicker, red thinner). (B) Stratigraphic section flattened on the Middle Eocene maximum flooding surface. Gravity flows of regression of lowstand system tract are concentrated in the Vaza-Barris Trough depocenter (SE-69 and SE-82). Sandstones of transgressive system tract are at the same position, with maximum flooding surface at the N-447 level. Section location in the inset with the Middle Eocene isopach map (blue ticker, red thinner).

barrier was constructed, which trapped sandy sediments behind it and resulted in expressive siliciclastic and carbonate sand deposits from coastal systems (Fig. 11C). As a consequence, areas downdip of the AP were relatively starved in allochthonous coarse sediments. The DS and the Northwestern DT were still sand deposition sites along relay ramps. Carbonate lobes, composed of sediments, eroded from the AP, locally filled the
DT and the GT. The step between the EP and the VBT was filled during the Middle Eocene and the gradient decreased. The depocenter was still on the VBT, but migrated updip to the area close to the GP and the IMST, where sandy siliciclastic sediments were concentrated on proximal slope deltas supplied by remobilized coastal sediments. During the main sediment supply, flows reached areas as far as the Middle Eocene 


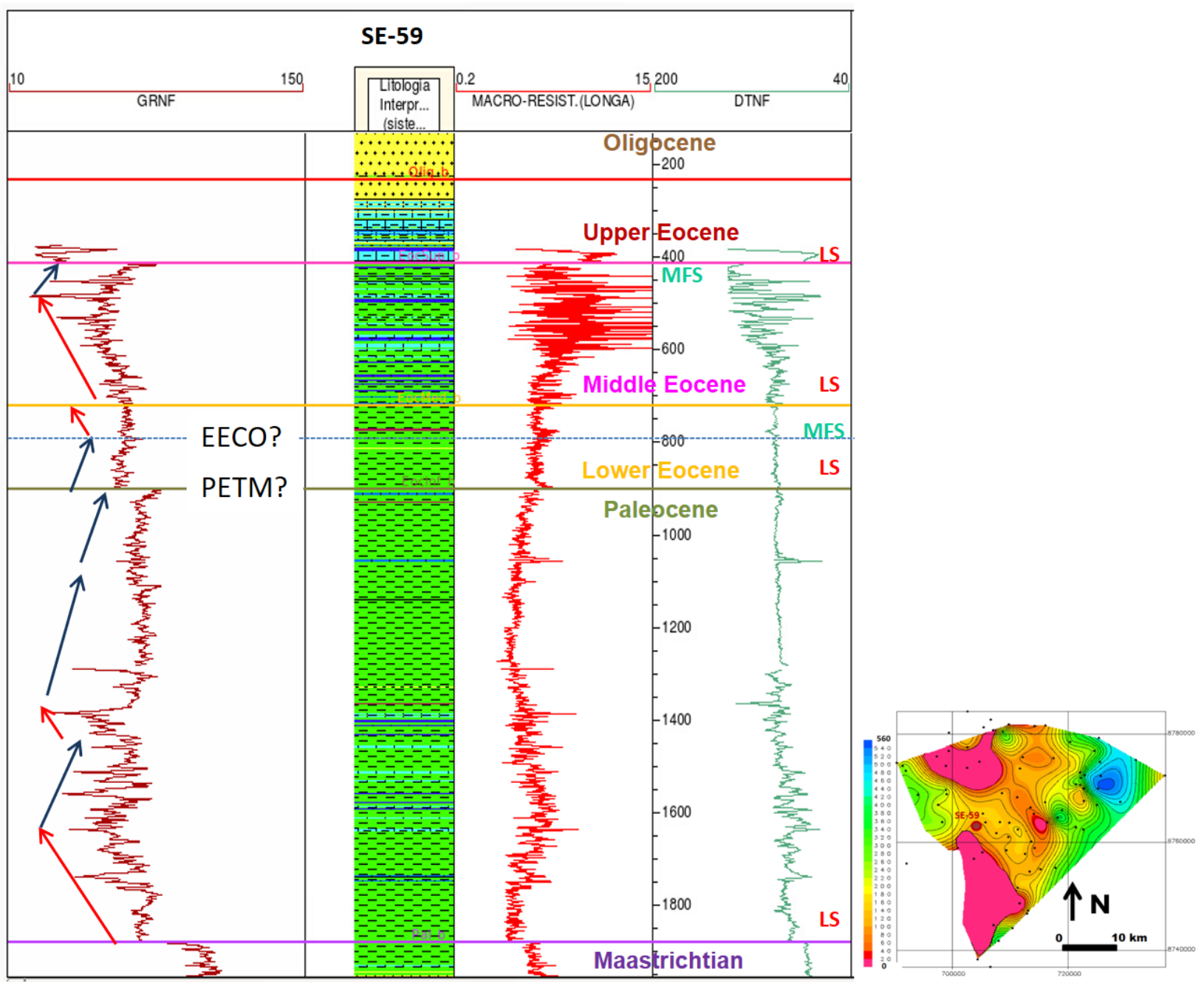

SL: Sequence Limit; MFS: Maximum Flooding Surface; PETM: Paleocene-Eocene Thermal Maximum; EECO: Early Eocene Climate Optimum.

Figure 13. Stratigraphic zoning for Paleocene and Lower Eocene in the SE-59 well. From left to right: gamma Rays log (GR) is on track 1 (horizontal lines indicate interpreted breaks on trends), lithological profile is on track 2. Resistivity log is on track 3 , and p-wave sonic log on track 4. Retrogradational trend in blue and progradational in red arrows.

depocenter, but a significant part of them was trapped updip. At this time, the deltaic distributive systems prograded towards the limits between the platform and the slope.

\section{DISCUSSION}

Pedrão (2004) characterized the Upper Paleocene to Ypresian interval of the Mosqueiro Low as a mainly transgressive interval, correlated to EECO event and Paleocene-Eocene Thermal Maximum (PETM) ofZachos et al. (2001), with maximum flooding surface at the $\mathrm{N}-410$ biozone level. The analysis of the genetic stratigraphy confirmed the retrogradational trend of the Ypresian interval, related to EECO, but with maximum flooding surface at the N-420 biozone level (Figs. 12A and 13). Climate conditions explain why there are sandy deposits in TST in the Lower Eocene record. Some of these sandstones have glauconite at top and base, also suggesting them as transgressive deposits.

Cainelli (1992) defined the Eocene base unconformity as the main sequence boundary of the Piaçabuçu Group in SergipeAlagoas Basin. The stratigraphic analyses of this work suggest the Middle Eocene basal unconformity as the main sequence boundary of the Piaçabuçu Group, at least at the Mosqueiro
Low (Figs. 7A and 7B). This suggestion is based on the erosion profile of this surface-reaching Paleocene, Senonian, and even Coniacian sections. This unconformity may be related to the uplift due to deep water magmatism in a local scale. Progradational trend continuation along the Bartonian and Priabonian could be related to the continental uplift caused by the main deformation phase of the Andean Orogeny, the Incaica Phase, also in Bartonian Age (Hascke et al. 2016).

The Eocene deformation is related to the reactivation of basement faults in the Western sector of the area, where it is stronger, and is associated with halokineses in the Eastern sector, where it is weaker. The reactivation of the deformation in small segments of the normal faults is a piece of evidence suggestive of transtension, like in the GT (Figs. 7A and 7B). The SW-NE geological sections present locally anomalous thicknesses in positive (convex up) features, similar to harpoon structures, which suggest compressive deformation associated with directional shear (Figs. 6A, 7A, and 7B). The transpressive deformation is important in the VBT, whereas distensive components may have acted in the structuring of the GT, DS, and DT. As consequence, the DT was the main depocenter during the Ypresian, and the VBT during the Lutetian-Bartonian and Priabonian (Fig. 14). 


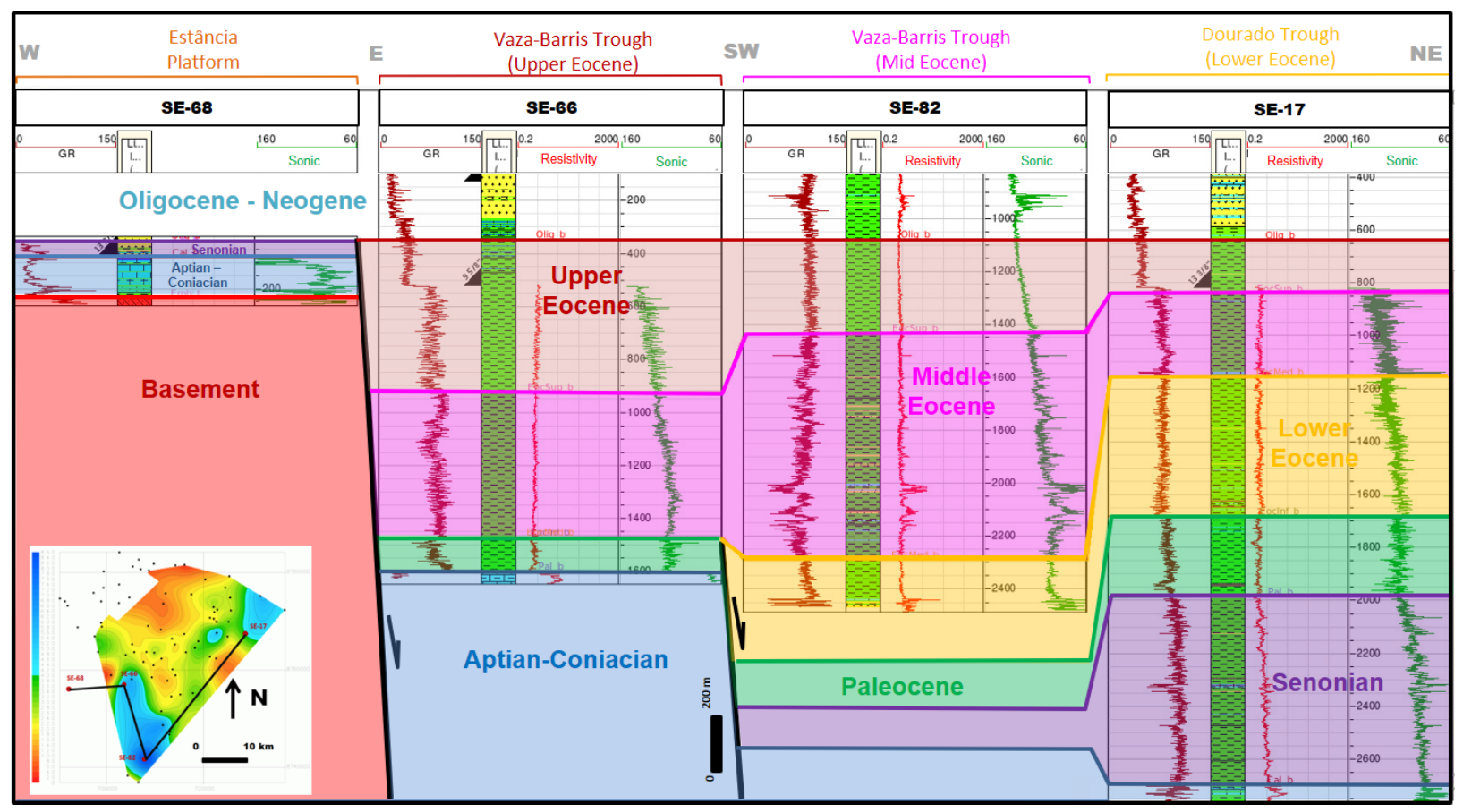

Figure 14. Arbitrary stratigraphic section flattened near the base of the Oligocene unconformity. The main depocenters of the Eocene Series are featured; the Dourado Trough during the Ypresian and the Vaza-Barris Trough during the Lutetian-Bartonian and Priabonian. Basement deformation at the Estância Platform (West) controlled limits of the Mosqueiro Low. Section location in inset with the Middle Eocene isopach map (blue thicker, red thinner).

Chemostratigraphy studies can clarify the correlation of EECO with N-410 or N-420 biozones in order to understand the real age of this event in Mosqueiro Low and also the Sergipe-Alagoas Basin. These studies can be extended to the new deep-water wells, where full datasets were collected. These wells drilled igneous rocks hosted in Paleocene and Eocene intervals, which can be dated by geochronology in order to improve biozone age and correlation with regional and global events.

3D seismic mapping will improve structural horizons, isopach maps, and the definition of the structural limits of features. New sampling on wells can also improve genetic stratigraphy and paleogeography interpretations.

\section{CONCLUSIONS}

The Mosqueiro Low was compartmentalized in plateaus, steps, and troughs. There are two main structural trends: N-S dipping to the E, associated with E-W faults, and NE-SW dipping to the SE, associated with NW-SE faults dipping to the NE. The Eocene Series was divided into three intervals: Ypresian, Lutetian-Bartonian, and Priabonian. The DT was the depocenter during the Ypresian, where siliciclastic and carbonate sands were concentrated, possibly related to differential subsidence. The Ypresian was the muddiest interval, deposited mainly in drowning and transgressive conditions, with good correlation with the EECO (Zachos et al. 2001), as published by Pedrão (2004) and suggested in this work by log wells correlation. The VBT was the depocenter of the Middle and Upper Eocene intervals. The main deformation phase and sediment influx occurred in the Middle Eocene (Lutetian), when the first Eocene carbonate platform was built (AP) and expressive sandstone lobes reached the most downdip areas of the VBT. In the Upper Eocene, the AP attained its maximum development in thickness and area.

During the Eocene, the VBT migrated gradually to W-SW. The integration of these interpretations suggests the unconformity at the base of the Middle Eocene as the main sequence boundary of the Eocene in the Mosqueiro Low. The subsidence increased as the result of intense magmatism in deep to ultradeep waters, and with an uplift of the onshore area to the West. The preliminary structural analysis suggests that there was a post-Eocene compressive deformation phase. These deformation phases may be related to the successive collapses of the EP associated with a distensive regime, with a local compressive component, as well as with the halokineses in the Central and Eastern areas of the Mosqueiro Low. An accurate structural analysis is necessary to understand the different phases of deformation to which this structural compartment was subjected.

\section{ACKNOWLEDGEMENTS}

The database used in this paper can be found in a master's degree work (Rancan 2017). We thank Petrobras for supporting this project and for providing resources. We also thank Unesp University for its support. C.C. This work is dedicated to all people who believe in science and have a collective sense of humanity in the face of the calamity we are experiencing, especially in the Republic of Brazil, a sad and abandoned nation. 


\section{ARTICLE INFORMATION}

Manuscript ID: 20200104. Received on: 04/15/2021. Approved on: 04/30/2021.

C.C.R.: main author, this paper is derived from his master's degree project results. R.R.: main advisor. W.S.L.: second advisor. C.B.: reviewer, improved structural and stratigraphy ideas.

Competing interests: The authors declare no competing interests.

\section{REFERENCES}

Antunes R.L., Melo J.H.G. 2001. Micropaleontologia e estratigrafia de sequências. In: Severiano Ribeiro H.J.P. (Ed.). Estratigrafia de seqüências: fundamentos e aplicações. São Leopoldo: Editora Unisinos, p. 73-98.

Antunes R.L., Shimabukuro S., Oliveira L.C.V., Zucatti A.L.R., Costa S.O., Scarparo A.A.C., Lima F.H.O. 2004. Em busca da bioestratigrafia de alta resolução - a performance do zoneamento de nanofósseis calcários da Petrobras. Boletim de Geociências da Petrobras, 12(2):421-427.

Bender F. 1957. Stratigraphic Units in Sergipe Basin. Petrobras Internal Report, 49. 23 p. Aracaju.

Cainelli C. 1992. Sequence stratigraphy, canyons and gravity mass-flow deposits in the Piaçabuçu Formation, Sergipe-Alagoas Basin, Brazil. Doctoral Thesis, Universtity of Texas, Texas, $466 \mathrm{p}$.

Campos Neto O.P.A., Souza-Lima W., Cruz F.G. 2007. Bacia de SergipeAlagoas. Boletim de Geociências da Petrobras, 15:405-415.

Catuneanu O. 1996. Reciprocal architecture of Bearpaw and post-Bearpaw sequence, Late Cretaceous-Ealry Tertiary, Western Canada Basin. PhD Thesis, University of Toronto, Toronto, $301 \mathrm{p}$.

Catuneanu O. 2006. Principles of Sequence Stratigraphy. Oxford: Elsevier.

Catuneanu O., Galloway W.E., Kendall C.G.S.T., Miall A.D., Posamentier H.W., Strasser A., Tucker M.E. 2011. Sequence Stratigraphy: Methodology and Nomenclature. Newsletter on Stratigraphy, 44(3):173-245. https://doi. org/10.1127/0078-0421/2011/0011

Chagas L.S. 1996. Tectono-sedimentação das bacias do tipo rifte: aplicação na porção emersa da Bacia de Sergipe-Alagoas. Masters Dissertation, Universidade Federal do Rio Grande do Sul, Porto Alegre, 322 p.

Duarte A.G. 1936. Petróleo e condições para sua ocorrência no Estado de Sergipe. Mineração e Metalurgia, 1(3)116-117.

Exon N.F., Kennett J.P., Malone M.J. 2004. Leg 189 synthesis: CretaceousHolocene history of the Tasmanian Gateway. Proceedings of the Ocean Drilling Program, Scientific Results, 189. http://dx.doi.org/10.2973/odp. proc.sr.189.101.2004

Feijó F.J. 1994. Bacias de Sergipe e Alagoas. Boletim de Geociências da Petrobras, 8:149-162.

Frazier D.E. 1974. Depositional episodes: their relationship to the Quaternary stratigraphic framework in the northwestern portion of the Gulf Basin. Bureau of Economic Geology. Geological Circular, 4(1). 28 p.

Hascke M., Gunther A., Melnick D., Echtler H., Reutter K.J., Sheuber E., Oncken O. 2016. Central and southern Andean tectonic evolution inferred from arc magmatism. In: Oncken O., Chong G., Franz G., Giese P., Götze H.J., Ramos V., Strecker M., Wigger P. (Eds.). The Andes - Active Subduction Orogeny. Frontiers in Earth Sciences. Berlin: Springer, p. 337-353.

Helland-Hansen W., Martinsen O.J. 1996. Shoreline trajectories and sequences: description of variable depositional-dip scenarios. Journal of Sedimentary Research, 66(4):670-688. https://doi.org/10.1306/ D42683DD-2B26-11D7-8648000102C1865D

Kennett J.P. 1977. Cenozoic evolution of Antarctic glaciation, the circum-Antarctic Ocean, and their impact on global paleoceanography. Journal of Geophysics Research, 82(27):3843-3860. https://doi.org/10.1029/JC082i027p03843

Lana M.C. 1990. Bacia de Sergipe-Alagoas: Uma hipótese de evolução tectono sedimentar. In: De Raja Gabaglia G.P., Milani E.J. 1990. Origem e evolução das bacias sedimentares. Rio de Janeiro: Petrobras, p. 311-332.

Mohriak W.U., Bassetto M., Vieira I.S. 1997. Observações sobre a carta estratigráfica e a evolução tectono-sedimentar das bacias de Sergipe e Alagoas. Boletim de Geociências da Petrobras, 11 (1-2):84-115.

Molnar P. 1986. The geologic history and structure of the Himalaya. American Scientist, 74(2):144-154.
Mutti E., Papani L., Di Biase D., Davoli G., Mora S., Segadelli S., Tinterri R. 1995. Il Bacino Terziario Epimesoalpino e le sue implicazioni sui rapporti tra Alpi ed Appennino. Memorie di Scienze Geologiche, 47:217-244.

Pardo-Casas F., Molnar P. 1987. Relative motion of the Nazca (Farallón) and South American plates since Late Cretaceous time. Tectonics, 6(3):233248. https://doi.org/10.1029/TC006i003p00233

Pedrão E.P. 2004. Palinoestratigrafia e caracterização de paleoambientes da seção paleocênica-eocênica da Bacia de Sergipe. Doctoral Thesis, Universidade Federal do Rio de Janeiro, Rio de Janeiro, 253 p.

Ponte F.C., Potter P.E., Toffoli L.C., Barros M.C. 1975. Gênese e distribuição dos Arenitos Calumbi na Foz do São Francisco, Sergipe-Alagoas. Petrobras Internal Report.

Posamentier H.W., Allen G.P. 1999. Siliciclastic sequence stratigraphy: concepts and applications. Concepts in Sedimentology and Paleontology. Society of Economic Paleontologists and Mineralogists (SEPM), v. 7, 210 p.

Posamentier H.W., Vail P.R. 1988. Eustatic controls on clastic deposition II - sequence and systems tract models. In: Wilgus C.K., Hastings B.S., Kendall C.G.S.C., Posamentier H.W., Ross C.A., Van Wagoner J.C. (Eds.). Sea Level Changes - An Integrated Approach. Special Publication. Society of Economic Paleontologists and Mineralogists (SEPM), v. 42, p. 125-154.

Prothero D., Shwab F. 1996. Sedimentary Geology: an introduction to sedimentary rocks and stratigraphy. New York: W. H. Freeman and Company, p. 386-409.

Quadros F.B., Ferreira E.P., Viviers M.C., Costa D.S. 2015. Caracterização paleoambiental de depósitos eocênicos da Bacia de Sergipe-Alagoas, Brasil, com base em morfogrupos de foraminíferos bentônicos e palinomorfos. Revista Brasileira de Paleontologia, 18(3):413-428. http://dx.doi. org/10.4072/rbp.2015.3.07

Rancan C.C. 2017. Estratigrafia da Série Eoceno no Baixo do Mosqueiro, Bacia de Sergipe-Alagoas. Dissertação de Mestrado, Universidade Estadual Paulista "Júlio de Mesquita Filho", Rio Claro, 167 p.

Ring U., Johnson C., Hetzel R., Gessner K. 2004. Tectonic denudation of a Late Cretaceous-Tertiary collisional belt: regionally symmetric cooling patterns and their relation to extensional faults in the Anatolide belt of western Turkey. Geological Magazine, 140(4):421-441. http://dx.doi.org/10.1017/S0016756803007878

Rona P.A., Richardson E.S. 1978. Early Cenozoic global plate reorganization. Earth Planetary Science Letters, 40(1):1-11. https://doi. org/10.1016/0012-821X(78)90069-9

Ruefli W.H. 1963. Surface-subsurface correlation Sergipe-Alagoas. Petrobras Internal Report, 274, 104 p.

Schaller H. 1970. Revisão Estratigráfica da Bacia de Sergipe / Alagoas. Boletim Técnico da Petrobras, 12(1):21-86.

Sibuet J.C., Srivastava S.P., Spakman W. 2004. Pyrenean orogeny and plate kinematics. Journal of Geophysical Research, 109(B8):104. https://doi. org/10.1029/2003JB002514

Souza-Lima W. 2001. Macrofaunas campanianas e ambientes deposicionais da Formação Calumbi, Bacia de Sergipe-Alagoas, Brasil. Doctoral Thesis, Universidade Federal do Rio de Janeiro, Rio de Janeiro, 366 p.

Souza-Lima W., Andrade E.J., Bengston P., Galm P.C. 2002. A Bacia de Sergipe-Alagoas: evolução geológica, estratigrafia e conteúdo fóssil. Aracaju: Fundação Phoenix Publications, 34 p.

Svensen H., Planke S., Malthe-Soresse N.A., Jamtveir B., Myklebust R., Eidem T.R., Rey S.S. 2004. Release of methane from a volcanic basin as a mechanism for initial Eocene global warming. Nature, 429(6991):542-5. https://doi.org/10.1038/nature02566

Zachos J., Pagani M., Sloan L., Thomas E., Billups K. 2001. Trends, rhythms, and aberrations in global climate $65 \mathrm{Ma}$ to Present. Science, 292(5517):686693. https://doi.org/10.1126/science.1059412 